\title{
Capacity Building and Skill Development among Female Entrepreneurs in Ido Zone, Nigeria: Implication for Adult Education
}

\author{
Oluwatoyin Dorcas Alese Ph.D. \\ Department of Arts Education, Adekunle Ajasin University \\ Akungba-Akoko, Ondo State
}

Doi:10.5901/mjss.2013.v4n11p680

\begin{abstract}
About half the nation's population are Females of which a good percentage engage in entrepreneurial activities of the informal sector because they lack relevant skills to increase their potentials and further break into the formal sector. The study investigated the impact of capacity building and skill development on 150 Female entrepreneurs in Ido Zone Nigeria. The study adopted descriptive research design of the survey type using multiple regression $(F(3,131)=9.467, R .4 .22, R 2=1.78, A d j, R 2=$ $1.59 ; p<.0 .5)$.It was found that capacity building /skill development contributed significantly to their socio -economic empowerment. However, recommendation was made that with Adult Education practices, Female entrepreneurs will benefit better while Adult Education would have fulfilled the gown and town relationship.
\end{abstract}

Keywords: Female entrepreneurs, capacity building, skill development, Adult Education, town and gown.

\section{Introduction}

Generally, it is believed that an impressive commitment to human capital formation breeds buoyant economy in nations. Human capital development is the increase in acquisition of capacities which is both human and institutional (Adedeji and Bamidele, 2002). The Nigerian government had since recognized the importance of capacity building when Late Enahoro cited by Aroge (2000) advocated that every enterprise within the Nigerian economy, public or private should build its human resources without which Nigeria cannot achieve development.

The task of achieving economic development made Nigeria embark on training of her citizenry. However, vested interest was placed on formal training in educational institutions such as universities, polytechnics and management development institutions perhaps, because of her colonial experience and training.

Nigeria is now faced with the fact that her crude oil can no longer take her to the development stage nor create job opportunities for her teeming population. With an estimated population of about 140 million people NPC (2006) in which women are about half, Nigeria depended on oil which generates about $90 \%$ of foreign exchange earning and $75 \%$ of government revenue contributing about $30 \%$ of GDP but employs only $3 \%$ of the labour force (Akpobasah, 2004). Graduates of Nigerian tertiary institutions find it very difficult to secure employment, little wonder that most universities this and polytechnics now incorporate entrepreneurship studies into their curricula.

Nigeria needs women and men with creative and innovative abilities to transform the state - led economy to a market-driven economy which will impact significantly on the nations' economy

Emeagwali (2006) affirms that unless Africa significantly increases its intellectual capital, the continent will remain irrelevant in the $21^{\text {st }}$ century and beyond. He further reiterated that Africa needs innovators and people to create and implement progressive ideas. These are entrepreneurial impetus. 'Entrepreneurship is very vital in the economic development of any nation. It avails enormous opportunities in growing indigenous enterprise culture which constitutes the most viable and veritable vehicle for self-reliance and sustenance. Entrepreneurship is a sub-sector of the economy through which meaningful economic restructuring activities that target employment generation, food security, rapid industrialization and poverty alleviation can be achieved.

Women entrepreneurship in developing economies like Nigeria accounts for a substantial portion of economic production and trade because women entrepreneurship is not new in Nigeria. Infact it is a socio-economic process, often coming in the form of skill acquisition whereby trainees acquire the skills inherent in the family and skillful people around them. Entrepreneurship is empowering as it has the potential of developing human resources through traditional and modern apprenticeship in trades and occupation. It provides opportunities for skill acquisition to promote balanced economic growth and development. 
No doubt the impact of women entrepreneurship cannot be overemphasized in Africa and Nigeria especially, in the informal sector and at a time that white colar jobs are no longer available. A sizeable percentage of women now head households.

Although, record does not capture the percentage of women in entrepreneurship in Nigeria, their entrepreneurial activities especially in Agriculture, services and industry abound. The female share of entrepreneurial activities in subSaharan Africa which Nigeria belong accounts for $44.3 \%$ in Agriculture, $28.2 \%$ in Industry and $46.9 \%$ in services in 1996.Similarly, 43.8\%, 27.0\% and 46.2\% respectively in 2004 . Again, $43.7 \%, 26.4 \%$ and $46.1 \%$ in 2005 while,

Female entrepreneurial activities recorded $43.7 \%, 26.7 \%$ and $46.1 \%$ in 2005 (Ilo, 2007).

A cursory look at the above indicate that women entrepreneurial activities predominate in the Informal sector. Informal sector activities make a significant impact and contribution to the economic development of the country and economic prosperity of a large segment of the community even if we fail to accord the sector with much degree of importance in our national developmental consideration and strategies (Wright, 1991). It took Nigeria a long time to recognize the activities of the informal sector more so, as it involves a large percentage of women who had always been engaged in entrepreneurial activities.

It is however, important to accord the activities of the sector more recognition especially, with the promotion of a private sector driven economy in Nigeria now. Until recently, Nigeria suppressed entrepreneurial impetus in her citizenry especially, among women who predominate the informal sector. The wherewithal of a thriving entrepreneurship development is lacking. Women entrepreneurs thus operated in an underdeveloped enterprise culture.

Women have the ability of creating jobs for themselves and generating employment for others. The ILO indicates that in the year 2006, $41 \%$ of the women employed in Africa are self employed and they are made up of women employers and own-account workers. Women in Africa have the potential of being self employed. Infact in Nigeria today women have devised coping strategies for unemployment by engaging in businesses in the formal sector than their male counterparts perhaps because of the easy entry. Although, women participate in various training organized by religions organizations, Non-governmental Organizations, self- help groups and government often times the training are a had-hoc of which manifest in a variety of trades through apprenticeship or directly from peers and family members. This indicate poor mastery of the theoretical aspect. However, some of these training were also more of theory than practice.

Entrepreneurship training could be received through educational exposure, pre-start-up technical training and during various phases of developing and expansion of enterprise. However majority of the female entrepreneurs level of formal education is low they also lack technical and development and exposure training could lead to expansion of their enterprise. However the major reason why entrepreneurship is prevalent in the informal sector of the economy. It is on this basis that this paper sought to investigate the activities of female entrepreneurs in skill development and how far their capacities are being built towards enhancing their socio-economic development and that of the society.

\section{Research Questions}

i. What will be the correlation between the capacity building and skill development of Female entrepreneurs on their socio-economic empowerment?

ii. What are the impediment toward building the capacity of female entrepreneurs?

iii. How far have they been able to transfer the skills to others?

\section{Statement of the Problem}

The importance of capacity building and skill development among the people of a society cannot be overemphasized. A nation cannot attain development if she neglects or refuses to put an impressive commitment on her human capital development. Capacity building is therefore, salient to the development of the individual and the nation at large.

Female entrepreneurs are quite energetic and contribute to the socio-economic development of themselves and their immediate society where their enterprises are situated. However, majority of them are unable to cross the ladder from being owners of micro enterprises of the informal sector to a stronger formal enterprise owner and export oriented category. More so, as majority of them operate with little or no formal education, technical and expansion of skills training. This paper therefore, investigates how capacity building and skill development could enhance the productivity of female entrepreneurs. 


\section{Methodology}

The study we adopted descriptive survey research design and this enhanced the collection of data from a sample of female entrepreneurs who engage in capacity building and skill development activities. The skills are Beads making/wire work; tie and dye, cattering and computer analysis. These are the skills that are predominantly practiced by the female entrepreneurs in the area.

The participants for the study were one hundred and sixty female entrepreneurs. This number arose from a purposively selected number of 40 participants each from the 4 selected skills using stratified and simple random sampling techniques. The ages of the participants range from 20 to 55- years. 120 (75\%) participants are married 28 $(17.5 \%)$ are single parents and $12(7.5 \%)$ are windowed. Only 60 (37.5\%) had the Basic education 25(15.6\%) are secondary school graduates while, $75(46.9 \%)$ do not have formal education.

The study was delimited to Ido Local Government Area in Ido, Oyo State. Ido houses some villages where rural women are prevalent. A lot of them farm and sell farm products in rural markets close to them. They have also acquired some entrepreneurial training through self-help groups, Non-governmental and governmental initiatives. A questionnaire tagged "Capacity Building for Female Empowerment Scale" was used to elicit responses from respondents. A total of 160 questionnaires were administered to the respondents, 150 were returned and appropriately filled. This formed the basis of data analysed for the study. Given the fact that a good percentage $(46.9 \%)$ of the respondents are not exposed to formal education, the study also made use of Focus Group Discussion (FGD) to elicit responses from the participants. A total of 4 Focus Group Discussion sessions were conducted with respondents.

Table 1: Focus Group Discussion Schedule of the study

\begin{tabular}{|l|c|c|c|c|}
\hline \multicolumn{1}{|c|}{ Skills } & Location of GDG & Number of session & Date & No of members persession \\
\hline Beads making/ wire works & Apete & 1 & June 10.2012 & $6-10$ \\
\hline Tie and dye & Akufo & 1 & July 6,2012 & $6-10$ \\
\hline Catering & Erinwusi & 1 & June 22,2012 & $6-10$ \\
\hline Computer analysis & Ido & 1 & June 13,2012 & $6-10$ \\
\hline
\end{tabular}

\section{Hypothesis}

What will be the correlation between the capacity building and skill development of female entrepreneurs on their socioeconomic empowerment

Table 2:

\begin{tabular}{|l|c|c|c|c|c|c|c|c|}
\hline \multicolumn{1}{|c|}{ Variables } & F- ratio & Sig. of $\mathbf{P}$ & $\mathbf{R}$ & $\mathbf{R}^{\mathbf{2}}$ & $\mathbf{A d j}_{\mathbf{R}} \mathbf{2}$ & $\boldsymbol{\beta}$ & $\mathbf{T}$ & $\mathbf{P}$ \\
\hline Capacity building/skill development & 9.467 & .000 & .422 & .178 & .159 & .295 & 3.491 & .001 \\
\hline Female socio empowerment & & & & & & .125 & 1.462 & .146 \\
\hline Female economic empowerment & & & & & & -.211 & -2.638 & .009 \\
\hline
\end{tabular}

The table above showed that the linear combination effect of capacity building/skill development, Females socio empowerment and Females economic empowerment was significant $\left(F(3,131)=9.467 ; R=.422, R^{2}=.178\right.$, Adj $^{2}=$ $.159 ; p<.05)$. The independent/predictor variables jointly accounted for a variation of about $18 \%$

\section{Discussion of Findings}

The result of this study show that there is a significant relationship between capacity building and skill development and socio-economic empowerment of female entrepreneurs $\left(F(3,131)=9.467 ; R=.422, R^{2}=.178\right.$, Adj $\left.R^{2}=.159 ; p<.05\right)$. In line with literatures (Aroge, 2000; FGN, 2001; Mbacham, 2001; UNDP, 2006; Oladapo, 2006; and Tengey, 2009). They report that building the capacity of the people fills identified gaps and needs, in terms of human resource and stem poverty. The survey findings corroborate the qualitative data generated through the Focus Group Discussion. For example, even the participants that are formally literate agree that:

We realize that entrepreneurship training is good o. each trade and vocation has its peculiarity which is a good avenue for making money and developing oneself. (FGD Participants, Apete, Ibadan June 10, 2012) 
This affirms the International Labour Organization (2008) that a coherent policy building, linking education and skills development to today's investment, trade and macro economic policies that generate future employment growth can help governments and societies improve the employability of workers, enhance the productivity and competitiveness of enterprises and promote the inclusiveness of growth which can serve as a powerful catalyst for realizing the universal goal of decent work for all.

Also, the Beads making/ wire work participants said:

Anti mi, ko sohun to dabi ise owo o. E wo awon eeyan o lo goolu mo nigbati awon atilaawi ti n re kawon mole ati pe ileke wa wuyi pupo..... Ewo seko 'ye yin bayi. FGD Participants Akufo July 6,2012.

Meaning:

My sister, there is nothing like craftwork People no longer are gold as much as before since robbers are visiting them in their houses And also our beads are beautiful .... Then dressing the researcher see, is it not beautiful on you? FGD Participants Akufo July 6,2012.

Yet the computer analysts submit:

Entrepreneurship training is good but those of you in the university should help us tell government that provision of materials like our computer is salient to capacity building. We are just trying. Many a times, we contribute money which takes more time to get equipped. FGD Participants Ido, Ibadan June 13, 2012

The above indicate that female entrepreneurs are committed and painstaking in the acquisition of entrepreneurial skill. These confirm (Manuh, 1998; Oladapo, 2006 and Hulbert, 2007) that women are painstaking in entrepreneurial activities. Hulbert maintained that there is a powerful option for personal empowerment through entrepreneurship.

Again, the caterers had this to say:

Our involvement in capacity building training is good and this has empowered us but, majority of us in this section had poor educational background and catering has gone beyond that those that are educated among us can move freely into offices, club houses and the like with our business cards and well meaning people patronize us. Even people like you. Abi, if you want to do party now, can you cook for yourself or give it to your siblings wives the way it was practiced before? (FGD participants Erinwusi, Ibadan June 22, 2012)

This further confirms Oladipo (2006)

As high as $70 \%$ of the non-literate members of Nigeria today are women and usually reside in the rural areas. Investing in formal and non-formal education and training for girls and women has proved to be one of the best means of achieving sustainable and economic growth in any nation. Thus any meaningful programme for women must address their accessibility to formal education, literacy, vocational and technical training. (p. 154)

Also, the tie and dye FGD session asserts:

Our training process is good and we are able to transfer our skills as you can see, there are apprentices. This is because Adire is used internationally. Look at that 'Mama', she tours Europe like Mokola but government still needs to enhance our products. We want to be known all over the world. Tell them to involve us in policies affecting our country. If government recognize us better than this and continue to give us training, for those coming up and those who want to do exports, it would have been better. People in Nigeria go to Dubai and other countries to buy their products. What stops those people from coming here to buy as well.

It further agrees with Manuh (1998) that:

Training programmes are needed to help women develop their technical competence to enable them to be better informed, better infiltrate the political and economic structures... and help them gain the maximum competence and means. The relative contribution and levels of significance of variables reveal that capacity building and skill development $(\beta=295, p<.05)$ Females socio-empowerment $(\beta=.125, p>.05)$ and Females economic empowerment $(\beta=.211, p<.0-5)$

Hence, while capacity building/skill development and Females Economic empowerment were significant, Female Socio empowerment was not. The reason for this is not far fetched candidly, women come together in groups, forming collectives and engaging in developmental activities. However, rather than using same opportunities and strategies for 
expansion of entrepreneurial activities trivial issues such as coming together for parties and the like take priority in their social gathering.

On the basis of the above, the researcher believes that Adult Education could be used to grow the entrepreneurial activities of women. As discussed earlier in this paper and according to the findings of this study the level of education of majority of Female entrepreneurs is very low even in starting and expanding business.

The town and gown relationship in academics should be fully employed here, where Adult Education will make use of its andragogical method, all that REFLECT entails and the imperatives of change.

\section{Conclusion}

The level at which female entrepreneurs operate is still very low whereas, they are a good source of manpower. According to Hassan (2011) manpower refers to human power supplied by physical and or mental work of people rather than machines. No doubt, capacity building and skill development enhances the manpower of a nation and building women's competencies will go along way to developing the society at large while raising the socio-economic level of the individual. The fact remain that Adult Education has a major role to play in achieving the World Bank's knowledge based economy.

\section{Recommendations}

- There is no other time than now for the Government, Non-Governmental Organizations and International agencies to embark on functional capacity building of women entrepreneurs if they are serious about reducing poverty in developing countries and the world.

- Capacity building centres should be well equipped to allow for good teaching as teaching without materials will not enhance competencies as required.

- Before capacity building programmes are initiated the target audience must be involved since they are the recipients

- Female entrepreneurs should harness the opportunity of groups to enhance productivity, new opportunities and marketing values

- Universities with the responsibility of contributing to their societies should employ all Adult Education values and attributes to develop the entrepreneurial capabilities of women for expansion otherwise women entrepreneurship will remain at the subsistence level.

- Institutions should empower units of Adult Education towards achieving this goal.

\section{References}

Adedeji S.O and Bamidele R.O 2002. Economic impact of Tertiary Education of Human Capital Development in Nigeria in P.I. Ozo-Esan and G. Eubuomwan (eds) Human Resources Development in Africa. The Nigeria Economic Society, (NES) Department of Economics University of Ibadan, Ibadan.

Akpobasah, .M 2004. Development Strategy/or Nigeria. A paper Presented A-at a 2-Day Seminar Organized by the Oversea Development Institute London.1617 June 2004.http://66.102.9104/Search pq= Mgu 9i x67 kk.j:www.odi.orguk./speeches/Nigeria 2004/Akpobash\%2520paper \%2520web.pdf

Aroge, S.T. 2000. An Analysis of Training Programme and skills utilization of the Nigerian Telecommunications Limited. Ph.D Thesis Department of Adult Education University of Ibadan pp278.

Capital Development in Nigeria in P.I. Ozo-Esan and G. Eubuomwan (eds) Human Resource Development in Africa. The Nigerian Economic Society (NES) Department of Economic University of Ibadan, Ibadan.

Emeagwali, P 2006. Ideas not money Alleviate Poverty mhtml:file:// E:/titi.mhtRetrieved21/10/2009

Hassan, M.A 2011 Manpower Development for Workers in Tertiary Institutions: Distance Learning Approach.

Hulbert, W 2007. Fostering Empowerment through Entrepreneurship Retrieved 03/08/09

International Education studies vol 4, No 2 May, 2011. www.ccsenet.org/ies

Manuh, T 1998 Women in Africa's Development Overcoming Obstacles, Pushing for progress http//www.un.org/ecosocdes/geninfo /afree/bpaper/maineng.htm Africa Recovery Briefing Paper II

Mbacham ,P.T 2001 Woman Empowerment and poverty alleviation for sustainable Development: A Comparative study of COWAD- Nigeria and VOCADER- Cameroon M. Ed Thesis Department of Adult Education University of Ibadan, Ibadan pp163.

Wright, E.H 1991. Training Opportunities in the Informal Sector of Freetown in Sierra Leone. A Research study in supplement to Adult Education and Development 37/1991 DVV 